\title{
習慣性咀嚼側の発現と咬合因子
}

\author{
檜山成寿，今村尚子，小野卓史，石渡靖夫，黒田敬之 \\ 東京医科歯科大学大学院医歯学総合研究科 \\ 顎顔面頝部機能再建学系専攻 \\ 顎顔面機能修復学講座 \\ 顎顔面矯正学分野 \\ （主任：黒田 敬之 教授） \\ 〔受付：平成11年 2 月 16 日〕
}

\section{Occlusal factors contributing to the development of habitual chewing side}

\author{
Shigetoshi Hiyama, Naoko Imamura, Takashi Ono, Yasuo Ishiwata, Takayuki Kuroda \\ Maxillofacial Orthognathics, \\ Maxillofacial Reconstruction, \\ Division of Maxillofacial/Neck Reconstruction, Graduate School, \\ Tokyo Medical and Dental University \\ (Director: Prof. Takayuki Kuroda) \\ [Received: February 16, 1999]
}

Key words: habitual chewing side, occlusal force, occlusal contact area, temporomandibular disorders

\begin{abstract}
The purpose of this study was to examine the relationship between the habitual chewing side, symptomatic side of temporomandibular disorders(TMD) and occlusal factors.

One hundred patients, from whom informed consents were obtained, participated in this study. They were questioned about their habitual chewing sides and TMD symptomatic sides. Occlusal contact was examined with Dental Prescale $50 \mathrm{H}$, type $\mathrm{R}$; the patients were instructed to bite as hardly as possible for 3 seconds in the intercuspal position. The occlusal force and the occlusal contact area were analyzed with the Occluzer. The statistical test for the proportion and the chi-square test for independence were carried out.

54 patients had their habitual chewing side in the right side and 46 in the left. The greater occlusal force was recorded in the habitual chewing side in 72 patients and in the opposite in $27(\mathrm{p}<0.01)$. The larger occlusal contact area was recorded in the habitual chewing side in 65 patients and in the opposite in $30(\mathrm{p}<0.01)$. With regard to TMD, among 36 unilateral symptomatic patients, the habitual chewing side coincided with the symptomatic side in 26 but not in $10(\mathrm{p}<0.05)$.

It is inferred that the occlusal factors such as occlusal force and occlusal contact area in the intercuspal position could contribute to the development of an habitual chewing side, and the TMD symptomatic side also might be close relationship with the habitual chewing side.
\end{abstract}

連絡先： ₹ 113-8549 東京都文京区湯島 1-5-45 
抄録 本研究は，習慣性咀嚼側と咬合因子および顎関節症状側との関連について検討することを目的とす る.

東京医科歯科大学歯学部附属病院矯正科を受診した患者 100 名（13４0歳：平均年齢22歳）を被験者と した．実験の前に，全ての被験者に対し実験の趣旨を十分説明し承諾を得た．習慣性咀緭側および顎関節 症状側は問診にて決定した。咬合状態の診査は，デンタルプレスケール50H, type R（富士写真フィルム社 製）を用い，被験者には咬頭嵌合位における 3 秒間の最大咬みしめを指示した。オクルーザーFPD703 （富士写真フィルム社製）を用いて咬合力および咬合接触面積を算出，左右側での優位な側をそれぞれ主 咬合力側および主接触側と定義し，これらと習慣性咀翾側との関係を検討した．統計学的検定には比率の 検定および $\chi 2$ 独立性の検定を用いた。

100名中，習慣性咀還側が右側の者54名，左側の者46名で，統計学的に左右差はみられなかった。習慣 性咀嚼側と主咬合力側が一致する者72名，一致しない者27名，習慣性咀夁側と主接触側が一致する者65名 一致しない者30名で，一致する者が有意に多かった $(\mathrm{p}<0.01)$ ．また，年齢および Angle 分類に基づく咬合 状態の結果に対する影響は示されなかった。顎関節症状に関しては，片側に症状を有する36名のうち，習 慣性咀嚼側と顎関節症状側が一致する者 26 名，一致しない者10名で，一致する者が有意に多かった $(\mathrm{p}<0.05)$.

習慣性咀嚼側の決定には, 咬合力および咬合接触面積が一因子として寄与している可能性が示唆された. また習慣性咀嚼側において顎関節症状が発症しやすいことが示された.

\section{I. 緒 言}

咀嚼時, 左右側いずれかの側が好んで用いられること がしばしば認められる1，2)。このような咀嚼運動およ びその作業側は，それぞれ習慣性咀嚼運動および習慣性 咀緭側と呼ばれている ${ }^{11}$ 。この習慣性咀嚼側の発現は, 歯科治療上様々な問題を生じるのみならず3４，，顎顔 面成長発育の不調和 $\left.{ }^{5}\right)$ および顎機能異常との関連 ${ }^{6)} も$ 指摘されている。習慣性咀嚼側の成因として，広範な力 リエ ${ }^{71}$ ，歯痛，歯の欠損，歯列不正 ${ }^{81}$ 等が報告され ている。したがって, 習慣性咀嚼側の発現は, 中枢性機 序や先天的要因によるというよりはむしろ，末梢性の後 天的要因によるといわれている81.

一方, 習慣性咀畄側と咬合との関連については, 関連

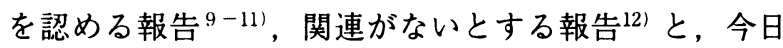
でもなお意見の一致をみない，さらに，習慣性咀嚼側と 顎関節症発症との関連に関しても関連を認めないとする 報告 ${ }^{12 ， 13)}$ がある一方，習慣性咀嚼側において顎関節症 状の発症しやすい可能性を示唆する報告 $\left.{ }^{10}, 11\right)$ もある.

本研究は, デンタルプレスケール診査により得られた 咬合力および咬合接触面積のデータに基づき，習慣性咀 嚼側発現に寄与する因子について検討するとともに，習 慣性咀翾側と顎関節症状側との関連についても検討を加 えることを目的とする。

\section{II. 方 法}

\section{1. 被験者}

東京医科歯科大学歯学部附属病院矯正科を受診した矯 正治療開始前の患者, 男性41名，女性59名，計100名を 被験者とした．図 1 に全被験者の年齢分布を示す。13歳 から40歳, 平均年齢22歳であった．被験者選択の基準は, 永久歯列を有し，カリエスによる歯冠の崩壊，処置中の 歯および欠損歯がないこと，上下顎左右同名歯が全て揃

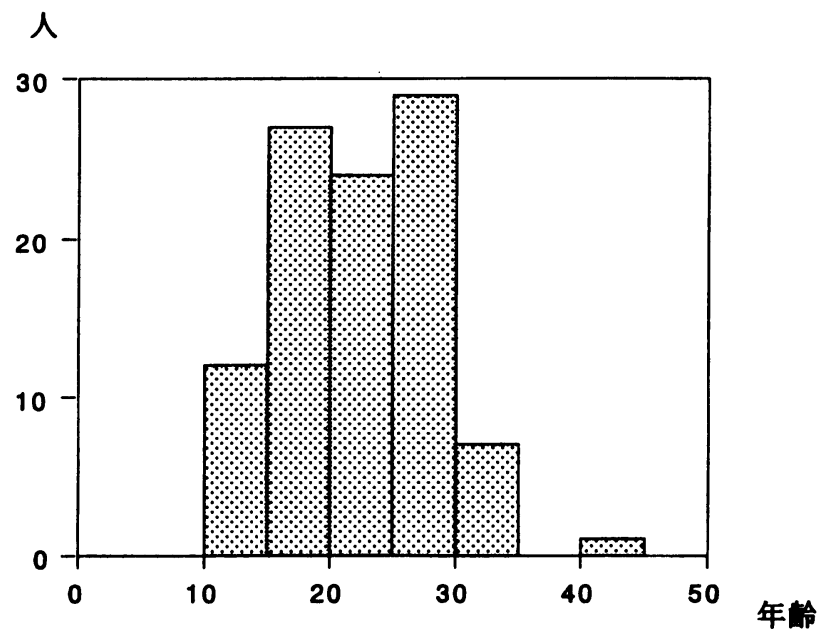

図 1 被験者の年齢分布

Fig. 1 Age distribution of the subjects 


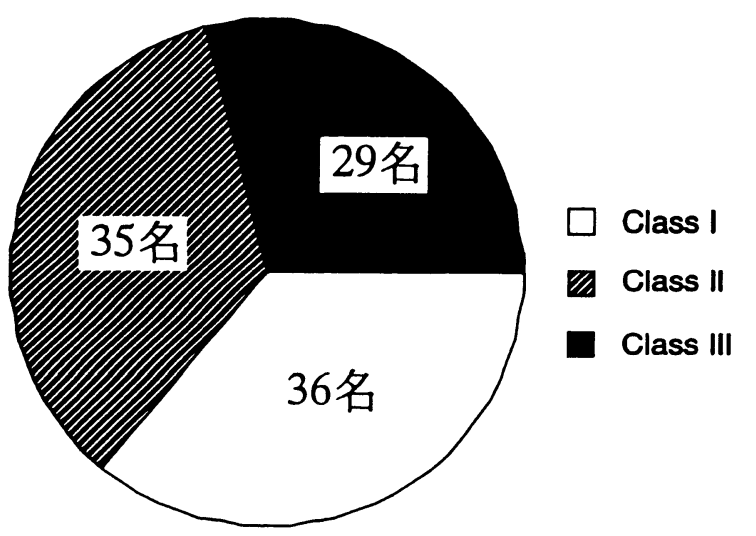

図 2 被験者100名の咬合状態

Fig. 2 Angle classification of the subjects

っていること, 下顎切歯 1 歯の幅径以上の下顎の著しい 側方偏位がないこととした。全被験者の咬合状態を Angle分類により診査した結果を図 2 に示す. Angle Class I が36名, Class II が35名, Class IIIは29名であった. 各被験者に対しては, 実験の内容について十分な説明を 行い，同意を得た上で実験を開始した。なお，本実験の 被験者としては, 後述する問診により習慣性咀嚼側を自 覚している者のみを対象としている。

\section{2. 習慣性咀嗳側の判定}

本研究における習慣性咀嚼側の判定は, 各被験者に対 する問診にて行った。すすおち, 被験者にチューインガ ム（シュガーレスガム：ワーナー・ランバート社製）を 任意に咀嚼させ, 左右側のどちらを主に用いて咀嚼を行 っているか, また, 左右側それぞれにおいて咀嚼した時, いずれの側がより咀嚼しやすいと感じるかについて問診 した.なお, 被験者の中には過去と現在の習慣性咀嚼側 が異なっている者もいたが, この場合, 現在の習慣性咀 嚼側を採用した。

\section{3. 顎関節症状側の判定}

本研究における顎関節症状側の判定も問診にて行っ た，過去および現在において，顎関節雑音および疼痛を 経験した側を症状側とし, 右側, 左側, 両側掞よび顎関 節症状なしの 4 群に分類した.

\section{4. 咬合診査}

本研究における咬合診査は, デンタルプレスケール 50H, type R（富士写真フィルム社製）を用いて行った. 被験者を柬科治療用椅子に着座させ, 頭部は安頭台につ けさせた，デンタルプレスケール感圧シートを被験者の
表 1 習慣性咀嚼側の側性

Table 1 Distribution of the laterality of habitual chewing side

\begin{tabular}{|c|c|c|}
\hline \multirow{2}{*}{ 習慣性咀嚼側 } & 右 側 & 54名 $\left[\begin{array}{l}\text { 男性：18名 } \\
\text { 女性：36名 }\end{array}\right.$ \\
\hline & 左 側 & 46名 $\left[\begin{array}{l}\text { 男性: } 23 \text { 名 } \\
\text { 女性: } 23 \text { 名 }\end{array}\right.$ \\
\hline
\end{tabular}

口腔内へ挿入した後, 咬頭嵌合位における 3 秒間の最大 咬みしめを指示した。この記録操作を 2 回繰り返した。 記録されたデンタルプレスケールの分析は, オクルーザ 一FPD703（富士写真フィルム社製）を用いて行い，咬 合力および咬合接触面積を算出した。左右歯列のうち, 咬合力および咬合接触面積の優位な側をそれぞれ主咬合 力側および主接触側と定義し, 各々を解析データのバラ ンスデータより決定した。なお, 左右側の咬合力および 咬合接触面積が同じであった被験者については判定不能 とし, 解析から除外した。

\section{5. 統計分析}

統計処理には比率の検定および $\chi^{2}$ 独立性の検定を用 いた，有意水準は $5 \%$ \%ベルとした。

\section{III. 結 果}

\section{1. 咀嚼側性 (表 1 )}

被験者100名のうち, 習慣性咀嚼側が右側である者54 名, 左側である者46名で, 左右差は認められなかった。 これを男女別にみると, 男性41名中, 習慣性咀嚼側が右 側である者18名 $(44 \%)$, 左側である者23名 (56\%) と 左右差は認められなかった。一方，女性59名中, 習慣性 咀嚼側が右側である者36名 $(61 \%)$, 左側である者 23 名 (39\%) と右側が多い傾向にあったが, 有意差は認めら れなかった。

\section{2. 習慣性咀嚼側と主咬合力側の関係}

判定不能の 1 名を除く99名において, 習慣性咀嚼側と 主咬合力側とが一致する者72名,一致しない者27名で, およそ 3 対 1 の割合となった。統計学的検定の結果, 習 慣性咀嚼側と主咬合力側とが一致する者の割合が有意に 高かった（図 3 ). 


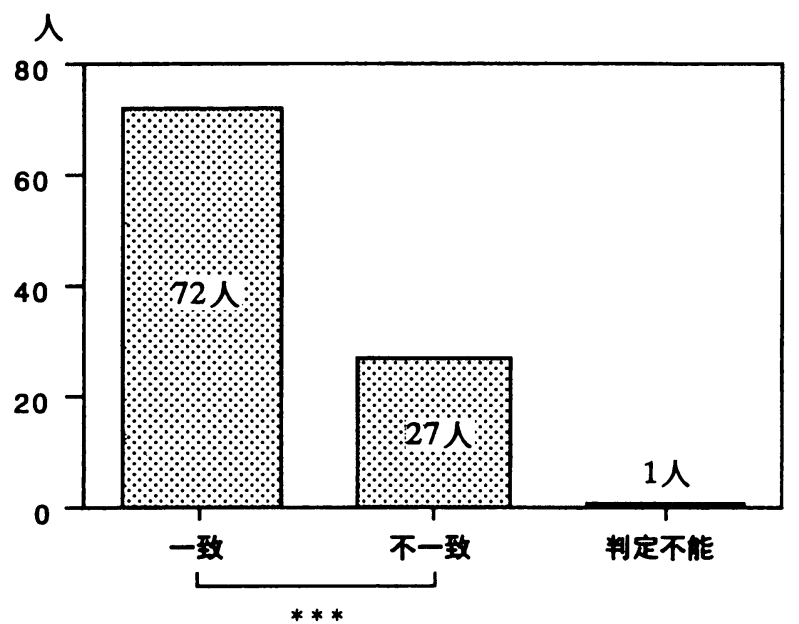

図 3 習慣性咀嚼側と主咬合力側との関係 *** : $\mathrm{p}<0.001$

Fig. 3 The relationship between habitual chewing side and preference side of occlusal force

$* * *: \mathrm{p}<0.001$

図 4 は, Angle分類別にみた習慣性咀嚼側と主咬合力 側との関係を示す. Angle Class Iに分類された 36 名中, 習慣性咀嚼側と主咬合力側が一致した者28名 $(78 \%)$, 不一致であった者7名 (19\%), 判定不能 1 名（3\%）で あった. Angle Class IIに分類された 35 名中，両者が一致 した者27名 $(77 \%)$ ，不一致であった者 8 名 (23\%) で あった．同様に，Angle Class 四の29名中，一致した者17 名 $(59 \%)$ ，不一致であった者 12 名 (41\%) であった。 Class I およびClass II 群に比べClass III群において一致率 がやや低く，不一致率がやや高い傾向にあったが，群間 に有意差は認められなかった。

\section{3. 習慣性咀嚼側と主接触側の関係}

判定不能の 5 名を除く95名において, 習慣性咀嚼側と 主接触側とが一致する者65名，一致しない者30名で，お よそ 2 対 1 の割合となった，統計学的検定の結果，習慣 性咀嚼側と主接触側とが一致する者の割合が有意に高か った（図 5 ).

図 6 は, Angle分類別にみた習慣性咀嚼側と主接触側 との関係を示す。Angle Class I に分類された 36 名中，習 慣性咀鲅側と主接触側が一致した者24名 $(67 \%)$ ，不一 致であった者11名 $(31 \%)$ ，判定不能 1 名（3\%）であ った．Angle Class IIに分類された35名中，両者が一致 した者 24 名 (69\%)，不一致であった者 9 名 $(26 \%)$ ，判 定不能 2 名 $(6 \%)$ であった。同様に, Angle Class III の

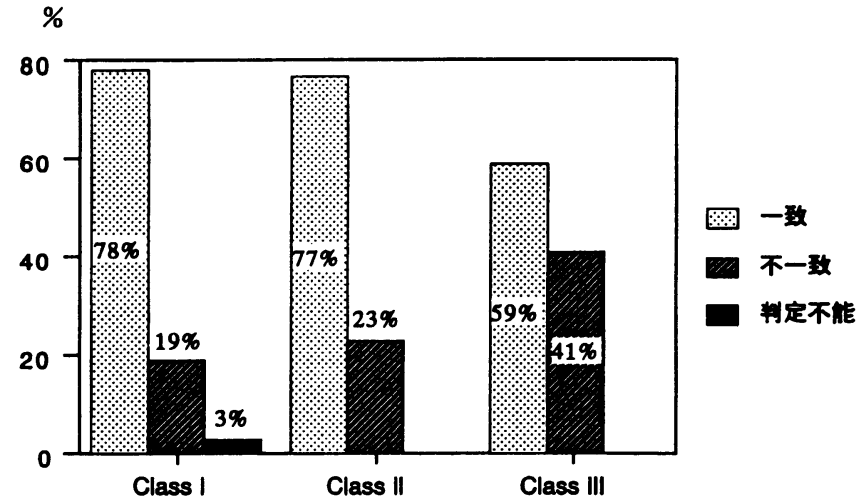

図 4 Angle 分類別にみた習慣性咀嚼側と主 咬合力側との関係

Fig. 4 The relationship between habitual chewing side and preference side of occlusal force in each group of Angle classification

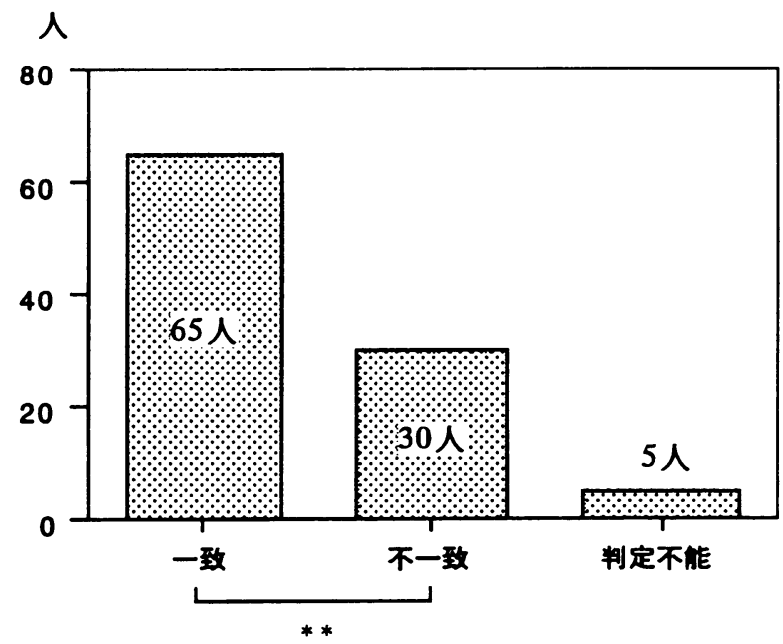

図 5 習慣性咀嚼側と主接触側との関係 **: $\mathrm{p}<0.01$

Fig. 5 The relationship between habitual chewing side and preference side of occlusal contact area ** $: \mathrm{p}<0.01$

29名中，一致した者17名 (59\%)，不一致であった者10 名 $(34 \%)$, 判定不能 2 名 $(7 \%)$ であった。 3 群とも に両者の一致率に関して同様の結果が示された。

4. 年齢別に検討した習慣性咀嚼側と主咬合力側および 主接触側の関係

図 7 および図 8 は，それぞれ習慣性咀嚼側と主咬合力 


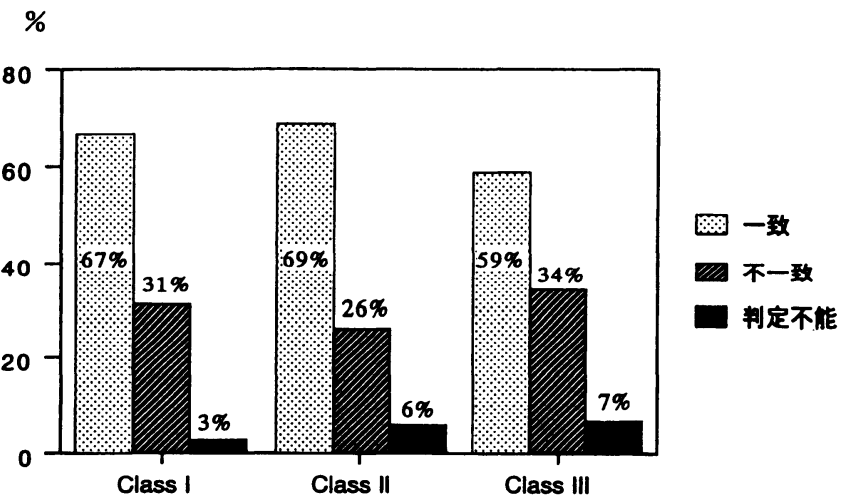

図 6 Angle 分類別にみた習慣性咀嚼側と主 接触側との関係

Fig. 6 The relationship between habitual chewing side and preference side of occlusal contact area in each group of Angle classification

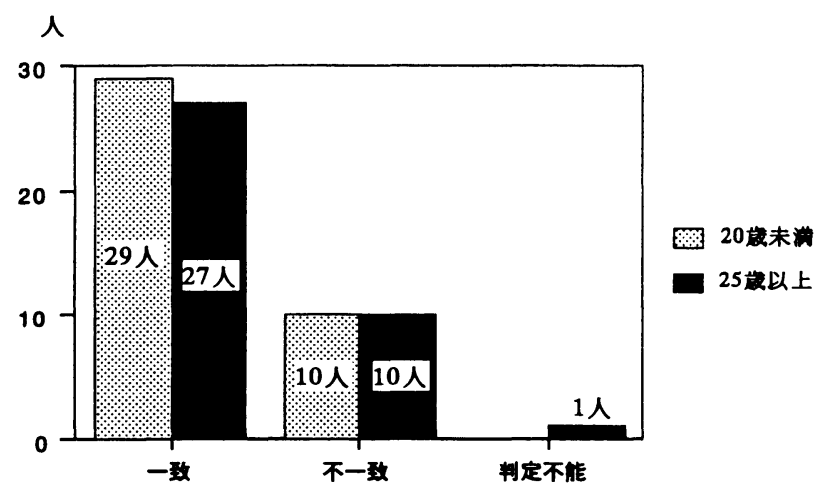

図 7 年齢別にみた習慣性咀嚼側と主咬合力 側との関係

Fig. 7 The relationship between habitual chewing side and preference side of occlusal force in two groups classified by age

側, および習慣性咀嚼側と主接触側との関係を, 20歳未 満の39名と, 25歳以上の38名について年齢別に比較検討 した結果である，年龄別による両者の一致，不一致の関 係に差は認められなかった。

5. 主咬合力側と主接触側の関係

判定不能の 6 名を除く94名において, 主咬合力側と主 接触側が一致する者84名, 一致しない者10名で，およそ 8 対 1 の割合となった. 統計学的検定の結果, 主咬合力 側と主接触側が一致する者の割合が有意に高かった（図

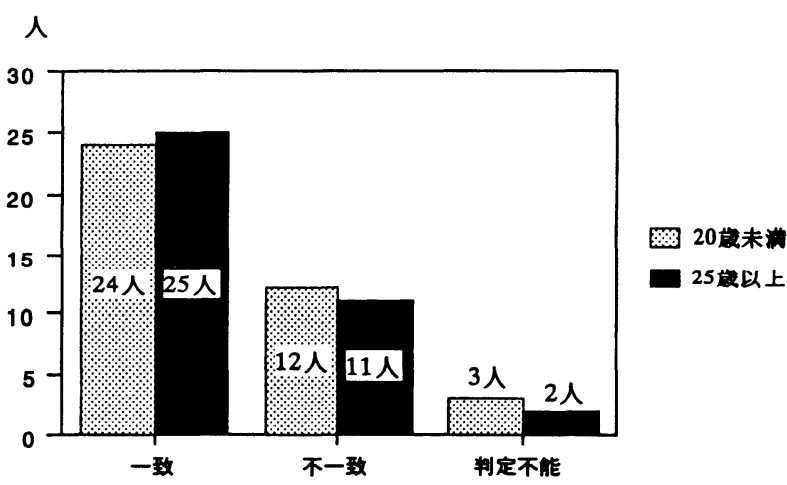

図 8 年齢別にみた習慣性咀嚼側と主接触側 との関係

Fig. 8 The relationship between habitual chewing side and preference side of occlusal contact area in two groups classified by age

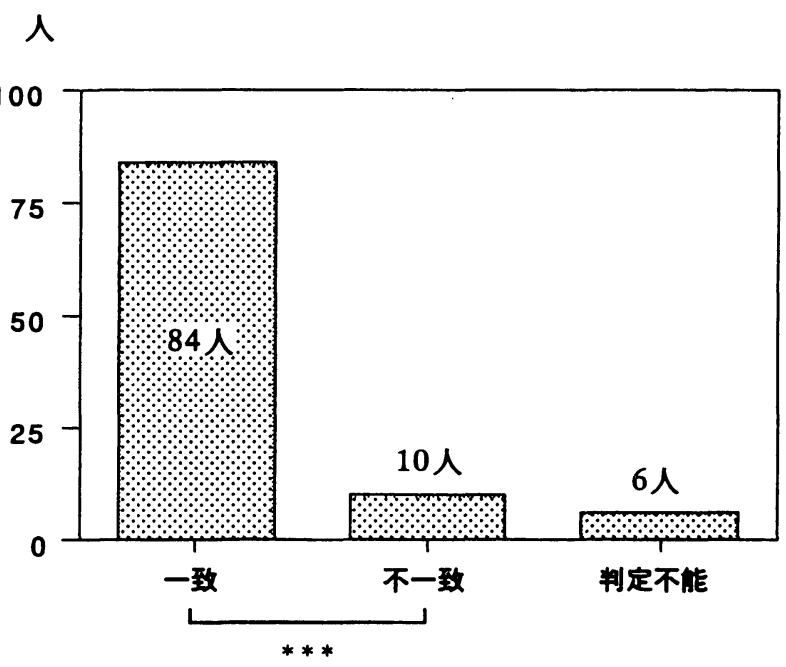

図 9 主咬合力側と主接触側との関係 ***: p $<0.001$

Fig. 9 The relationship between preference side of occlusal force and that of occlusal contact area $* * *: \mathrm{p}<0.001$

$9)$.

6. 顎関節症状

被験者 100 名のうち, 顎関節症の既往のある者 48 名 (男性17名，女性31名)，ない者52名（男性24名，女性28 名）で，ほほ同数であった，有症状者のうち，両側顎関 節に症状を有する者は12名（男性 4 名, 女性 8 名), 片 側顎関節に症状を有する者は36名（男性13名，女性23名） 
表 2 顎関節症状

Table 2 Number of symptomatic and asymptomatic subjects according to gender

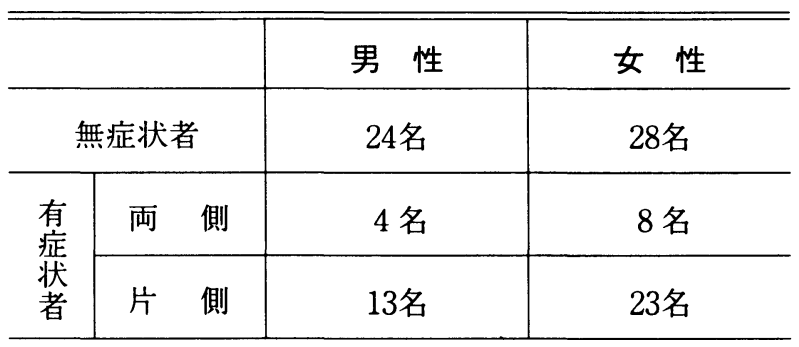

で, 1 対 3 の割合であった（表 2 ). 片側顎関節に症状 を有する36名のうち, 習慣性咀噮側と顎関節症状側が一 致する者26名，一致しない者10名で，その割合はおよそ 5 対 2 となり, 習慣性咀嚼側と䪽関節症状側とが一致す る者の割合が有意に高いことが示された（図10).

\section{V. 考察}

\section{1. 習慣性咀嚼側の判定法}

習慣性咀嚼側の判定には, 従来より様々な方法が用い られてきたが, 本研究と同様の問診による方法が最も多 〈行われている8 ${ }^{8}$ 11, 13-17). 一方, 石幡ら ${ }^{31}$ は咀嚼の第 一ストロークを重視し、これを咬み癖の判断に利用しょ うとしている. 藤井 ${ }^{10)} は$, 問診, 下顎の前後運動, 咬 合小面の分布状態, 実際に食事をする状態の観察などか ら総合的に判断している. Pond $ら^{12)}$ は, ニンジン咀緭 の観察から判断しており, Christensen ら ${ }^{18)}$ は, 咀緭開 始から15秒, 20 秒, 25 秒後に咀嚼を一時中断させ, この 時ガムの存在する側をもって習慣性咀嚼側としている。 さらに, 石神ら ${ }^{191}$, 倉知 ${ }^{201}$, 山村 ${ }^{21)}$ は, 可及的に 客観性をもたせ, かつ偏側咀嚼の程度を数量化する目的 で, 60秒間のガム咀嚼運動をシロナソグラフを用いて記 録し，得られた前頭面運動軌跡より各咀嚼ストロークの 咀嚼側を決定し, 全ストロークの50\%を超えた咀嚼側を もって習慣性咀嚼側としている. 倉知ら ${ }^{201}$ は, 問診に よる聞き取り, 咀嚼開始時の第一ストロークの咀嚼側か ら判定する方法, およびシロナソグラフによる咀嚼運動 の観察から判定する方法の 3 つの方法から判定される習 慣性咀翾側は比較的よく一致すると報告している。また 山村ら ${ }^{21)}$ も， 7 名の被験者全員で，ストローク数の多 い側と問診による習慣性咀嚼側が一致したと述べてい る. 以上の報告結果から, 本研究における習慣性咀嚼側 の判定は, 特別な装置を必要としない, 簡便な問診によ

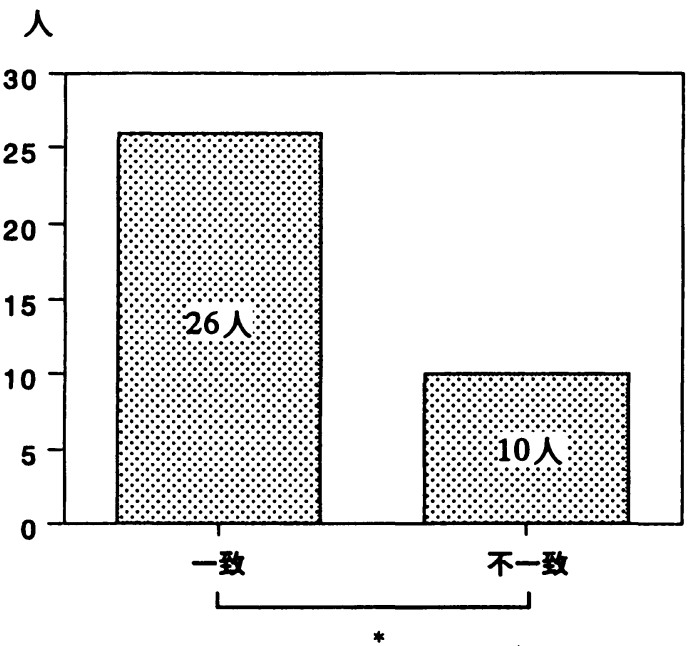

図10習慣性咀嚼側と顎関節症状側との関係 *: $\mathrm{p}<0.05$

Fig. 10 The relationship between habitual chewing side and symptomatic side of temporomandibular disorders

*: $\mathrm{p}<0.05$

る方法により行うこととした．荻本 ${ }^{17)}$ は，質問表を用 いた通常の問診による習慣性咀嚼側の判定と, 実際に咀 嚼様運動を行わせた後での問診（咀嚼後問診）による判 定を比較検討し, 咀畄後問診は通常の問診より信頼性な らびに検出率の高い方法であると述べている。この点を 考慮し, 本研究では, 被験者に実際ガム咀嚼を行わせた 後に問診を行った。

\section{2. デンタルプレスケールによる咬合診查}

近年, デンタルプレスケールを用いる咬合診査は, 歯 科臨床研究に広く普及してきており，その有用性に関す る報告が数多くみられる $22-31)$. しかしながら、デー夕 の再現性および精度には未だ検討の余地が残されてい

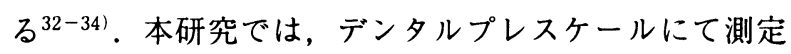
された咬合力および咬合接触面積のデータを定量的に解 析するのではなく, 単に歯列弓の左右側で咬合力がより 強く発現されている側, より咬合接触面積の多い側を判 断する手段として用いた。同一個体内で繰り返し計測を 行った時, 主咬合力側および主接触側の判定が左右逆転 することがあるかについて, 予備実験として10名の被験 者を用い再現性試験を行った。各被験者に対し, 咬頭嵌 合位における最大咬みしめを 3 回行わせることで採得さ れたデータでは, 全被験者において, 主咬合力側および 主接触側ともに全て同一側であった。佐藤ら ${ }^{291}$ は, 中 
等度以上の咬みしめ強さにおいて, 各菌牙の咬合力比は ほほ一定となると述べており, 袖山ら ${ }^{35)} も$, デンタル プレスケールによって計測された中心咬合と考えられる 位置での最大咬みしめ時の咬合力分布様相には再現性が あったと報告している。このことから, 左右側間の比較 を行う場合に咬合力比を採用しても，そのデータは安定 していると考えてもよいと思われる。ささらに山口ら ${ }^{321}$ は, プレスケールを用いた咬合接触部位の診査は, 中等 度以上の咬合力を負荷すれば信頼性が高く, 特に大自歯 部については，ほほ咬頭嵌合位の咬合接触部位を再現し 得ると述べている。 したがって，デンタルプレスケール を用いた咬合診查は, 本研究の目的に供し得る十分な再 現性を有するものと考えられた。

\section{3. 咀哷側性}

習慣性咀嚼側に関する従来の研究では，その側性に関 して見解の一致はみられていない。石原ら ${ }^{36)} は$, 習慣 性咀嚼側が右側である者が左側の者の 3 倍であったと報 告しており, 上田ら ${ }^{81}$ も, 右側がやや優位な傾向を示 し, 右側対左側が約 3 対 2 の割合であったとしている. さらに倉知ら ${ }^{201}$ は, 問診, 咀嚼第一ストロークからの 判定, シロナソグラフを用いた顎運動からの判定法いず れの方法においても, 咀徱の偏向性は右側の優位性が示 されたと述べている。一方, Pond ら ${ }^{12)}$, 桑原ら ${ }^{15)}$,

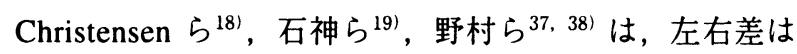
なかったと報告している，本研究の結果からは，習慣性 咀嚼側が右側である者が100名中54名, 左側であるもの が46名であり, やや右側が多いものの, 統計学的には有 意差は示されなかった。 これを男女別にみると, 男性で はやや左側優位の傾向がみられたが，女性では左側23名 に対し右側が36名と，約1.5倍右側が多かった，咀夁側 性の男女別検討を行った報告としては, 上田ら ${ }^{8)}$, 石原 ら ${ }^{36)}$ の報告があるが, 咀嚼側性に関して男女間で差は ないという結果を示している, 本研究の結果では, 統計 学的有意差は示されなかったものの, 女性において習慣 性咀嚼側が右側にやや多い傾向が認められた.

\section{4. 習慣性咀嚼側と咬合因子}

習慣性咀嚼側と咬合因子との関連について検討した報 告は少ない. Pond ら21は，中心位における片側での咬 合接触, 作業側および平衡側における臼歯部咬合干涉と いった咬合因子と習慣性咀嚼側との関連について統計学 的検討を加えたが，これらの咬合因子と習慣性咀嚼側と の間には関連は見いだせなかったと報告している。一方， Hildebrand $^{9)}$ は，側方グラインディング中に多くの歯の 接触する側を咀翾側として選択すると推測しており, 藤 ${ }{ }^{101}$ は, 正常有柬顎者の咬頭嵌合位における上下顎歯
の咬合接触状態を診査した結果, 左右での接触点数の差 の大きかった 2 名の被験者では習慣性咀嚼側で接触点数 が多かったことから，接触点数と習慣性咀嚼側との間に は少なからず関連性があることを推察している。しかし ながら，これは 2 名の被験者から得られた私見にすぎな い。また家入ら ${ }^{111}$ は，習慣性咀嚼側と歯牙ガイドとの 関連性について検討し, 習慣性咀嚼側では反対側に比べ 犬歯, 小臼歯の接触誘導が多く, 側方ガイドが確立して いること, また習慣性咀嚼側は顎運動時に平衡側干渉を 受けにくい側である可能性を示唆している。このように, 習慣性咀嚼側と咬合因子との関連については十分な裏付 けを得るには至っていない，そこで本研究では，咬頭嵌 合位における最大咬みしめ時の咬合力および咬合接触面 積という咬合因子と習慣性咀嚼側との関連について検討 したそその結果，咬頭嵌合位においてより大きな咬合力 を発揮し得る側および咬合接触面積の大きい側が習慣性 咀嚼側となる傾向が示された（図 3,5 )。咀嚼時に上下 顎歯の接触がより多く得られ，またより効率よく十分な 咀嚼力を発揮し得る側が習慣性咀嚼側となるであろうこ とは想像に難くない。しかしながら, 習慣性咀嚼側の発 現には，咬合以外の因子，例えば体重心の偏りおよび屃 の高さを含む体姿勢 ${ }^{14)}$, 顔面各部の形態 ${ }^{199}$, 下顎頭の運 動距離37) 等が関与している可能性も報告されており, このことが本研究において習慣性咀嚼側と主咬合力側お よび主接触側の一致しない者が $20 ３ 0 \%$ と比較的多くみ られたことを説明するものと思われる.

一方, Angle分類別に習慣性咀獣側と咬合因子との関 連について検討した結果, 習慣性咀嚼側と主咬合力側と の関係において，Class 回群ではClass I およびClass II 群 に比べ両者の一致率がやや低い傾向にあったが, 統計学 的有意差は示されなかった（図 4,6). Angle分類が上 下顎第一大臼歯の近遠心的対咬関係に基づく咬合分類法 であるため, 本分類法と歯列全体の咬合接触状態との関 連は低いであろうことが推測され，本研究の結果はこれ を支持するものと言えよう。

さらに, 加齢とともに種々の口腔内感覚情報に対する 反応性に変化が生じ，その結果として，習慣性咀嚼側の 発現および習慣性咀嚼側と咬合因子との関係に変化が生 じる可能性が考えられた。そこで本研究では，20歳未満 の39名と25歳以上の38名のそれぞれにおいて, 習慣性咀 嚼側と主咬合力側および主接触側との関係を検討した。 その結果, 年齢の違いによる有意差は認められなかった (図 7,8 ). 本研究で対象とした被験者は, 矯正科を受 診した永久歯列を有する者という限られた条件で選択さ れたため, 20歳未満と 25 歳以上という年齢層で分けたも 
のの，それぞれ15歳〜20歳および25歳～30歳という範囲 に多くの被験者が属する結果になった。このような近接 した年齢層に属する被験者群を対象としたことが, 有意 性の有無に影響を与えたことが考えられる．荻本 ${ }^{171}$ も 述べているように，個体の機能獲得の影響について検討 するには, さらに, 30歳, 40歳, 50歳といった幅広い年 齢層を対象とするべきものと考えられた。

\section{5. 䫟関節症状}

本研究における不正咬合患者 100 名のうち，顎関節有 症状者は48名 $(48 \%)$, 無症状者は52名 (52\%) であっ た. 不正咬合者を対象とした顎関節症状の発現に関する 疫学研究において, Williamson ${ }^{38)}$ は, 平均年齢12.9歳の 被験集団における有症状者率は $35.2 \%$ と報告している. 同様に宮崎ら ${ }^{399}$ は有症状者率33.6\%, 不島ら ${ }^{40)}$ は33.6\%, 田中ら ${ }^{41)}$ は $21.1 \%$, 藤崎ら ${ }^{42)}$ は35.2\% と報告している. これらの報告に比べ本研究における有症状者率は $48 \%$ と 高かったが，これは被験者集団の年齢の違いによるもの と思われる。この点について加藤ら ${ }^{43)}$ は，ロジスティ ック回帰分析を用いて顎関節症発症に影響を及はす因子 について検討した結果, 年齢が顎関節症の有症率を高め る方向で有意に影響を及ほすことが示された。本研究の 被験者の平均年齢は22歳であったが, これは先に挙げた 低い有症状者率を報告している研究の平均年齢12１5歳 と比較して明らかに高いものである. 本研究と同じ年齢 層における有症状者率として, 宮崎ら ${ }^{39)}$ は, 高校生で $41.4 \%$, 成人で $62.0 \%$ あったと述べており, 不島ら ${ }^{401}$ は，19歳以上では73.1\%と報告している。田中ら ${ }^{41)}$ は,

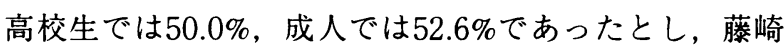
ら ${ }^{42)}$ は, 15 19歳の有症状者率は 5 割を超え, 25歳以 上になると 7 割近くになると報告している。これら同年 齢層を対象とした有症状者率をみると, 本研究の結果も ほほその範囲に入ってくるものとなり，このことは本研 究の被験者群が一般の不正咬合集団と大きく異なるもの ではないことを示しているものといえょう.

一方, 男女別の有症状者率に関しては, 本研究におい ては男性41名中17名 (41\%)，女性59名中31名（53\%） とやや女性に多い傾向がみられたが, 統計学的には有意 差は示されなかった。この点について加藤ら ${ }^{43)}$ は, 性 別は顎関節症発症に対する有意な因子ではないと結論し ている。また, 宮崎ら ${ }^{39)}$, 田中ら ${ }^{41)}$, 藤崎ら ${ }^{42)}$ も, 顎 関節有症状者率に男女差はなかったと報告しており，こ れらは本研究の結果を支持するものである.

さらに本研究では, 有症状者48名のうち症状が両側性 の者12名 (25\%)，片側性の者36名（75\%）であった。 中村ら ${ }^{44)}$ は両側性の者が $29.9 \%$, 片側性の者が $70.1 \%$,
藤田ら ${ }^{45)}$ は両側性が $12.5 \%$, 片側性が $87.5 \%$, 平松ら ${ }^{46)}$ は両側性の者が $27.5 \%$, 片側性の者が $72.5 \%$ と報告して おり, 本研究の結果もこれらの報告とほほ同様の結果と いえる.

\section{6. 習慣性咀嚼側と頻関節症状側との関連}

藤崎ら ${ }^{421}$ は，アンケート調查に基づき顎関節症発症 と習癖との関連について検討し, 偏側咀嚼が有症状者群 で有意に多かったと報告している。また平澤ら ${ }^{47)} も$ 同 様に，偏側咀嚼が有症状者に多かったと述べている。こ れらの疫学研究から, 顎関節症の発症に偏側咀嚼が一因 子として寄与している可能性が推測された。そこで本研 究においては, 習慣性咀嚼側と顎関節症状側との関連に ついても検討を加えることとした。

習慣性咀嚼側と顎関節症状側との関連について, Pond $ら^{121}$ は, 開口障害, 咀嚼障害, 開閉口時の下顎側 方偏位, 顎関節痛, 顎関節雑音, 咀嚼筋痛などの機能異 常と習慣性咀噮側との間には関連を認めなかったと報告 し, 浅野ら ${ }^{13)}$ も, 習慣性咀嚼側と顎関節症状側との間 には特に関連はみられなかったと述べている。これらの 報告に対し，最近，習慣性咀嚼側と顎関節症状側との間 の関連性を示唆する報告が多くみられる。上田ら ${ }^{81}$ は， 被験者数が 6 名と少なく傾向が判然とはしないが, 疾患 側と同側が習慣性咀嚼側であった者はいなかったと述 ベ, 顎関節症が習慣性咀嚼側の反対側に生じやすいとい う可能性を示唆している. 一方, 家入ら ${ }^{11}$ は, 開口障 害や顎関節疼痛などのより重篤な顎関節症状については さらに検討する必要はあろうが，軽度のクリックに関し ては, 習慣性咀緭側と同側に症状の出現する可能性があ ると述べている，本研究においては，習慣性咀嚼側にお いて顎関節症状の発現しやすいという有意な傾向が示さ れた（図10)。本研究における顎関節症状は多くがクリ ック等の関節雑音であり, 家入ら ${ }^{11)}$ と同様, より重篤 な顎関節症状あるいは筋症状側との関連については, さ らに検討の余地があると考えられる。寉木ら ${ }^{481}$ は，片 側咀嚼時の左右顎関節部負荷について, 生物学的顎関節 負荷モデルを用いて解析を行った．その結果，片側咀嚼 時に, 開始直後は非咀嚼側の顎関節により大きな負荷が 加わっているが, 咀嚼が進行して咀嚼運動がリズミカル になると，顎関節部負荷は左右均等に分散されると述べ， 作業側顎関節負荷が従来考えられているほど小さくない ことを示唆している. Gibbs ら ${ }^{49)}$ は, リプリケーターシ ステムを用いて咀嚼中の下顎運動を記録し，作業側下顎 頭は咀嚼サイクルの終末において下顎窩内で外側および 後方位を強いられることを示し，このことから不島ら ${ }^{401}$ は，片側咀嚼が長く続くと同側の顎関節の障害を起こす 
ことが考えられると述べている。またBoyd ${ }^{501}$ は，サル 顎機能時の顎関節関節面間圧力をトランスデューサーに て計測し, 咀嚼時に生じる顎関節負荷は, 作業側が非作 業側よりも大きかったと報告している。.これらの報告は, 顎関節症状発現に関連したメカニズムが, 習慣性咀嚼側 において実際にはたらいていることを示唆するものであ る.

本研究にご協力いただきました歯科矯正学第二講座各 位に感謝いたします。なお本論文の内容は，日本顎口腔 機能学会 第17回学術大会（1998年, 東京）にて発表し た.

\section{V. 文献}

1）長谷川成男：ヒトの咀嚼運動, 東京医科歯科大学歯 学部顎口腔総合研究施設編, 咀しゃくの話, 163-207, 日本歯科評論社, 東京, 1987.

2 ) Wictorin, L., Hedegard, B. and Lundberg, M.: Cineradiographic studies of bolus position during chewing, J Prosthet Dent, 26 : 236-246, 1971.

3 ）石幡伸雄，野村義明，鯉㴊秀明ほか：かみ癖につい て 第 1 報 臨床的立場からみたかみ癖の影響につ いて，顎頭蓋誌， 7 ：57-65, 1994.

4 ）大野肃英, 中村昭二, 石幡伸雄ほか：“啮みぐせ” への対応，日本歯科評論，632:65-136，1995.

5 ) 佐藤康守：咬筋機能の左右不均衡が下顎頭部の成長 発育に及ほす影響，阪大歯学誌，31：137-164, 1986.

6 ）續 肇彦：臨床カラーシリーズ 3 顎関節症の臨床, 65-89, 永末書店, 京都, 1987.

7 ) Goldaracena, P., Rey, R. and Martinez, C. : Dental caries and chewing side preference in Maya Indians, J Dent Res, 63 : 182, 1984.

8 ) 上田直克, 弓場直司, 田中昌博ほか：咀嚼得手側の 自覚に関する調査, 補緅誌, 35：708-714, 1991.

9 ) Hildebrand, Y.: Studies in mandibular kinematics, Dent Cosmos, 78 : 449-458, 1936

10）藤井哲則：正常有歯顎者における咬頭嵌合位とその 付近の側方咬合位での咬合様式, 九州歯会誌, 37 ： 250-264, 1983.

11）家入美香，松尾浩一，沖本公繪ほか：習慣性咀鱿側 と歯牙ガイドの関連性についての検討, 補緅誌, 37 : 961-973, 1993.

12) Pond, L.H., Barghi, N. and Barnwell, G.M.: Occlusion and chewing side preference, J Prosthet Dent, 55 : 498-500, 1986

13）浅野澄明，堀田一男，児玉 実ほか：顎関節症患者 の咬合像に関する調查（第1 報），補緅誌，18： 105-116, 1974.

14）石井弘二, 石垣尚一, 奥田真夫ほか：身体の平衡が 顎口腔機能に及ほす影響について (その一), 顎機 能, $4: 101-105,1985$.

15）桑原隆男, 瑞森嵩弘, 西尾公一ほか：咀嚼運動にお ける運動域ならびに閉口経路に関する研究, 補緅 誌, 29：106-115, 1985.

16）仁村秀由喜, 小林義典：咀嚼運動における主咀嚼側 咀嚼時と非主咀嚼側咀嚼時との差異, 補緅誌, 34 ： 1127-1139, 1990.

17）荻本多津生，小川隆広，梅本丈二ほか：問診による 習慣性咀嚼側の判定法の検討ならびに臨床診査結果 との関連，日顎誌，10：398-409，1998.

18) Christensen, L.V. and Radue, T.: Lateral preference in mastication: a feasibility study, J Oral Rehabil, 12: 421-427, 1985.

19）石神 元，横山佳郎，杉本裕紀ほか：顎機能と顔面 各部形態一特に習慣性咀嚼側との関係について一, 補緅誌，36・87特別号：207，1992

20）倉知正和, 石神 元, 横山佳郎ほか：偏側咀嚼の指 数表示について，補綴誌，36：1026-1031，1992.

21）山村善治，倉知正和，石神 元ほか：非習慣性咀喂 側咀嚼の持続が咀嚼運動に及ほす影響, 補緅誌, $37: 192-198,1993$.

22）荒木章純，伊藤 裕，佐久間重光ほか：新しい咬合 診査機器（Occluzer FPD703）による咬合の評価 その 1 正常者の習慣性閉口位について, 日本歯科 評論, $624 ： 187-194,1994$.

23）荒木章純，伊藤 裕，向田吉範ほか：新しい咬合評 価システム（デンタルプレスケール OCCLUZER） の臨床応用に関する一考察, 歯界展望, 84： 1007-1019, 1994.

24）鈴木哲也，渡邉竜登美，吉富信幸ほか：感圧シート を用いた新しい咬合圧測定システムの有用性，補緅 誌，38：966-973， 1994.

25）鈴木哲也，熊谷 宏，吉富信幸ほか：咬合圧測定シ ステムの臨床応用に関する研究，口病誌， 61： 25-33, 1994.

26）服部佳功，奥川博司，渡辺 誠：Dental Prescale を 用いた歯列における咬合力測定, 補緅誌, 38 ： 835-841, 1994. 
27）渡辺 誠，服部佳功：Dental prescale 50を用いた咬 合診断とその臨床応用一主に咬合力の強さを指標と した咬合診査法について一，歯界展望，84： 109-126, 1994.

28）木村朋義, 佐藤華織, 今上岳彦ほか：「デンタルプ レスケール」を用いた咬合接触圧の測定一咬合接触 圧の左右比に関する検討一, 北海道歯誌, 16 : 12-19, 1995.

29）佐藤智昭, 服部佳功, 渡辺 誠：咬みしめ強さと歯 列における咬合力分布, 顎機能誌, $2: 101-109$, 1996.

30）服部佳功, 佐藤智昭, 渡辺 誠: 咬みしめ時の歯列 における咬合力分布, 顎機能誌, 2 : 111-117, 1996.

31）小林義典, 志賀 博, 田中 彰ほか：プレスケール に関する臨床的研究ークレンチングの強さと咬合力 との関係一，顎機能誌，3:139-146, 1997.

32）山口泰彦, 久恒泰宏, 木村朋義ほか：デンタルプレ スケールを用いた咬合接触部位の診查法に関する検 討一咬頭嵌合位における咬合接触部位の検出率につ いて一，補緅誌，39：1113-1120，1995.

33）内山恵代, 丸山陽市, 小林和秀: 咬合圧測定システ ムを用いた咬合接触面積の評価法について, 日矯歯 誌, $56 ： 92-99,1997$.

34）志賀 博, 小林義典, 中島邦久ほか：プレスケール に関する臨床的研究, 日本顎口腔機能学会 第15回 学術大会プログラム・事前抄録集：6-7, 1998.

35）袖山亜紀, 篠ケ谷龍哉, 松元 誠：最大咬合力の歯 列内分布状態の再現精度, 口病誌, $65: 339-343$, 1998.

36）石原寿郎, 平沼謙二, 橋本 譲ほか：生米を試験食 品とする咀嚼粉研効率の算出基準について, 口病誌, $26: 620-622,1959$.

37）野村義明, 石幡伸雄, 鯉渕秀明ほか：かみ癖につい て 第 2 報 かみ癖と顎口腔系諸器官との関連性に ついて, 頡頭蓋誌, $7: 67-75,1994$.

38) Williamson, E.H.: Temporomandibular dysfunction in pretreatment adolescent patients, Am J Orthod, 72: 429-433, 1977.
39）宮崎晴代，茂木悦子，久保木裕子ほか：顎機能異常 についての矯正学的研究一第 2 報 矯正治療患者に おける臨床調査一, 日矯歯誌, $47: 590-600,1988$.

40）不島健持, 秋本 進, 高木建雄ほか：不正咬合者に おける顎関節症状の発現一澦関節症の成立機転に関 する一考察一，日顎誌，1：40-50，1989.

41）田中栄二, 丹根一夫, 作田 守: 不正咬合患者の矯 正科初診時における顎関節症の統計学的研究, 日顎 誌, 4 : 19-31, 1992.

42）藤崎臣弘，加藤嘉之，藤田幸弘ほか：不正咬合者に おける顎関節症に関するアンケート調査結果, 日顎 誌, 5 :64-77, 1993.

43）加藤嘉之, 五十嵐一吉, 檜山成寿ほか：顎関節症に 関与する因子の検討一性別, 年齢, 関節可動性につ いて一, 日顎誌, 10:71-80, 1998.

44）中村公雄, 山内哲義, 榎阪 朗ほか: 顎関節症患者 の統計的観察, 補経誌, $19: 232-237,1975$.

45）藤田 寛, 金井義明, 大登 剛ほか：䫟関節症の臨 床的研究 第 1 報 臨床統計的観察, 日口外誌, $26: 1508-1514,1980$

46）平松伸一, 渡辺誠, 許 重人ほか: 顎関節症の発 症に関与する咬合因子に関する臨床的研究, 補緅誌, $42: 686-696,1998$.

47）平澤純子, 石井昌子, 黒田敬之ほか：女子大学生に おける顎関節症の疫学的研究, 日顎誌, $7: 97-106$, 1995.

48）寉木拓男, 木尾正人, 矢谷博文ほか：片側咀嚼時咬 合相のバイオメカニクス，日顎誌， $3: 66-78$, 1991.

49) Gibbs, C.H. and Lundeen, H. C.: Jaw movements and forces during chewing and swallowing and their clinical significance, edited by Lundeen, H.C. and Gibbs, C. H., Advances in occlusion, 2-32, John Wright - PSG, Massachusetts, 1982.

50) Boyd, R.L., Gibbs, C.H., Mahan, P.E. et al.: Temporomandibular joint forces measured at the condyle of Macaca arctoides, Am J Orthod Dentofac Orthop, 97: 492-499, 1990. 